Article

\title{
Cycas micronesica Trees Alter Local Soil Traits
}

\author{
Thomas E. Marler $1, * \mathbb{C}$ and Murukesan V. Krishnapillai ${ }^{2}$ \\ 1 College of Natural and Applied Sciences, University of Guam, Mangilao, Guam 96923, USA \\ 2 Cooperative Research and Extension, College of Micronesia-FSM, Yap Campus, Yap 96943, \\ Federated States of Micronesia; muru@comfsm.fm \\ * Correspondence: marlert@triton.uog.edu or thomas.marler@gmail.com; Tel.: +1-671-735-2100
}

Received: 2 August 2018; Accepted: 11 September 2018; Published: 13 September 2018

\begin{abstract}
Cycad plants possess uncommon morphological, chemical, and ontogenetic characteristics and they may introduce localized changes in soil traits that increase habitat heterogeneity. We used mature Cycas micronesica K.D. Hill trees growing in a range of soil types in Guam, Rota, and Yap to quantify differences between the soils beneath target trees and paired non-target soils away from cycad trees. The chronic presence of a $C$. micronesica tree introduced numerous localized changes in soil traits, increasing the heterogeneity of elemental stoichiometry in the community. Nitrogen, carbon:phosphorus, and nitrogen:phosphorus were increased in target soils among every soil type. Carbon increased and phosphorus decreased in most target soils. The habitats revealing the greatest number of elements with differences between target and non-target soils were the habitats with acid soils. The greatest number of metals exhibiting differences between the target and non-target soils occurred in the impoverished sandy habitat. This is the first report that indicates a cycad tree increases community spatial heterogeneity by localized changes in soil chemistry. Contemporary declines in cycad populations due to anthropogenic threats inadvertently decrease this spatial heterogeneity and its influences on primary producers in the landscape then cascading effects on the food web.
\end{abstract}

Keywords: cycad; home field advantage; fertile islands; plant-soil feedback; soil legacy effects

\section{Introduction}

Cycas micronesica K.D. Hill is an arborescent cycad species (Figure 1a) with a native range that includes Palau, Yap, Guam, and Rota Islands [1]. These Micronesian islands are positioned in the western belt of the Pacific Ring of Fire from ca. $7.5^{\circ}$ to $14.1^{\circ} \mathrm{N}$ latitude. The 2003 invasion of Guam and 2007 invasion of Rota by the armored scale Aulacaspis yasumatsui Takagi caused widespread C. micronesica tree mortality [2-4]. This tree was the most numerous tree species on Guam at the time of the invasion [5], indicating that it served as a foundation species due to its abundance (Figure 1b). The density of the tree in Rota and Yap habitats was similar to or greater than in Guam habitats (unpublished data). The selective purging of this single species from in-situ and urban forests could lead to substantial ecological changes [4].

Cycad plants are unique in many respects, and more focused studies into cycad biology may inform contemporary research agendas [6,7]. Cycas micronesica is the only gymnosperm that is native to the Mariana Islands, produces long-lived leaves that senesce with high lignin/nitrogen and carbon/nitrogen traits [8], and like all cycads produce specialized coralloid root structures that house nitrogen-fixing cyanobacteria symbionts [6].

The international goals of threatened species recovery and ecological restoration are often hindered by the lack of benchmark information [4]. How does an attempt to return to some historical level of plant population health or ecosystem services occur if that historical benchmark is not quantified prior to the disturbances that generate the need for recovery or restoration? In that regard, 
we set out to determine the mineral and metal content of soils near $C$. micronesica trees to more fully understand cycad ecology. The information may increase our understanding of how healthy C. micronesica trees contribute to ecosystem services and how those services may be lost when the trees are killed by invasive pests.

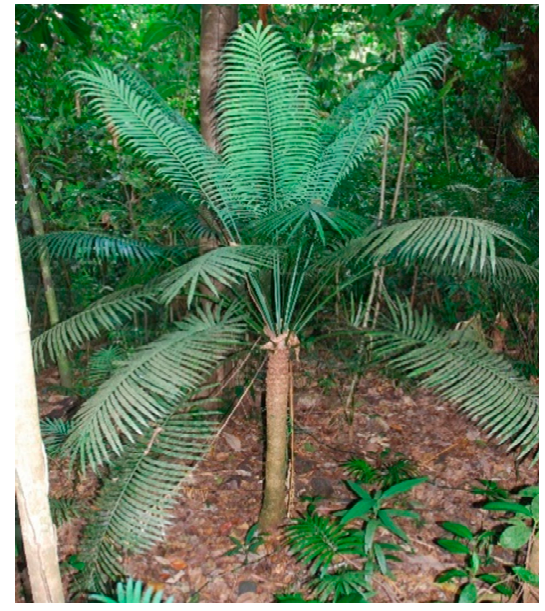

(a)

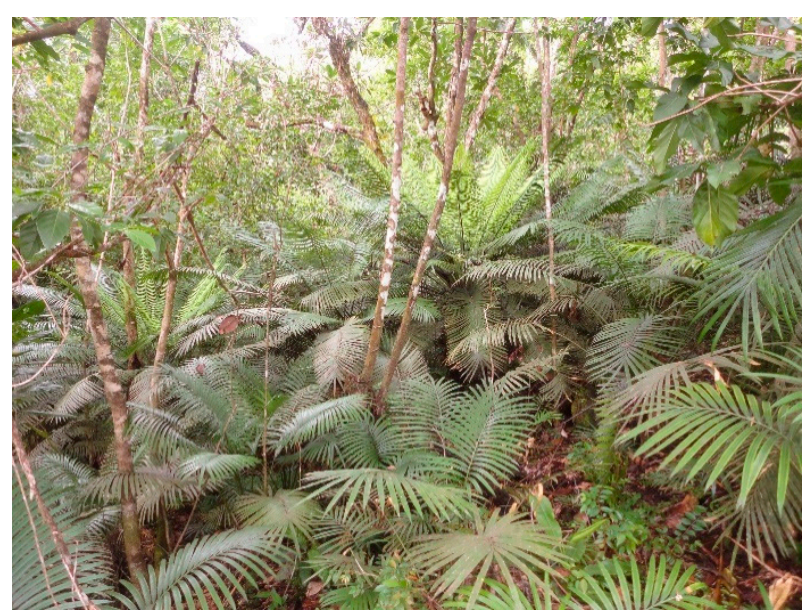

(b)

Figure 1. The arborescent Cycas micronesica tree exhibits a pachycaulous stem with radiating large compound leaves. (a) Isolated trees reveal the beauty and distinctiveness of this gymnosperm; and, (b) Extremely high densities illuminate the role as a foundation species in many of the habitats within its native range.

We were not interested in identifying mechanisms functioning in the means by which a healthy cycad tree directly interacts with its soils. Instead we set out to quantify soil traits within the leaf umbrella of large target cycad trees and compare those traits to the soils from nearby paired sites outside the zone of influence of the target plants. We tested the hypothesis that the soil traits beneath a mature cycad tree would differ from the soils that are outside the zone of influence, thereby increasing heterogeneity in community properties. When considering the importance of contemporary cycads to provide insights into the evolution of seed production and the ability to withstand mass extinction events that deleted countless other species from the biosphere [6], the fact that no cycad species has been included in the research on plant-soil feedback phenomena is surprising. This first look at the local contributions of a long-lived arborescent cycad species will fill this void.

\section{Materials and Methods}

We monitored the migration events of $A$. yasumatsui throughout Guam and Rota habitats during the years following the invasions, and for most habitats we recorded dates of initial C. micronesica plant infestations. For three habitats on Guam, we were able to collect soils to more fully understand the ecosystem contributions of the healthy $C$. micronesica trees prior to the A. yasumatsui infestations. These soils represent most of the soils throughout the native range of the tree species. Even though we were unable to collect soil samples from Guam's littoral sandy habitats prior to widespread plant mortality. We were able to collect soil samples on the island of Rota. The Yap C. micronesica populations do not have any biological threats to date. We augmented the Guam and Rota habitats with a Yap habitat to more fully understand how C. micronesica affects all the soils throughout its native range. This approach provided five habitats containing high density $C$. micronesica populations prior to the onset of non-native herbivore threats. Twelve paired micro-sites were selected in each habitat for sampling (methods below), and all the $C$. micronesica plants in excess of 1-m in height were counted within a linear $4-\mathrm{m} \times 100-\mathrm{m}$ transect in order to estimate the adult population density. 
An eastern Guam site was sampled 13-15 December 2004, and it contained 1159 trees per hectare. The karst soils formed in slope alluvium, loess, and residuum overlying limestone (Clayey-skeletal, gibbsitic, nonacid, isohyperthermic Lithic Ustorthents) [9]. The most common sympatric trees were Cynometra ramiflora L., Eugenia reinwardtiana (Blume) DC., Ochrosia mariannensis A. DC., Ochrosia oppositifolia (Lam.) K.Schum, and Pandanus tectorius Parkinson ex Zucc. Aulacaspis yasumatsui migrated into this habitat in February 2005. A western Guam habitat was sampled 4-7 March 2005, and it contained 1094 trees per hectare. The Guam cobbly clay soils were formed from sediment overlying porous limestone on uplifted plateaus (Clayey, gibbsitic, nonacid, isohyperthermic Lithic Ustorthents) [9]. The most commone sympatric trees were Aglaia mariannensis Merrill, Meiogyne cylindrocarpa (Burck) Heusden, Morinda citrifolia L., Ochrosia oppositifolia (Lam.) K.Schum, and Premna obtusifolia R. Br. Aulacaspis yasumatsui migrated into this habitat in May 2005. A southern Guam site was sampled 15-18 June 2005, and it contained 889 trees per hectare. The volcanic soils formed in residuum derived from tuff (very fine, kaolinitic, isohyperthermic Oxic Haplustalfs) [9]. The most common sympatric trees were Cocos nucifera L., Cynometra ramiflora L., Morinda citrifolia L., Pandanus dubius Spreng., and Pandanus tectorius Parkinson ex Zucc. Aulacaspis yasumatsui migrated into this habitat in February 2006. A Rota coastal habitat was sampled 9-11 July 2009, and it contained 1328 trees per hectare. The sandy soils were formed in water-deposited coral sand derived from coral reef formations (Carbonatic, isohyperthermic Typic Ustipsamments) [10]. The most common sympatric trees were Ficus prolixa Forst. f., Hernandia sonora L., Hibiscus tiliaceus L., Morinda citrifolia L., and Pandanus dubius Spreng. Aulacaspis yasumatsui migrated into this habitat in Oct 2009. A Yap habitat was sampled 3-5 March 2018, and contained 1242 trees per hectare. The soils were formed in residuum derived from green, chlorite, and talc schist (Clayey-skeletal, mixed, isohyperthermic Lithic Tropudalfs) [11]. The most common sympatric trees were Barringtonia racemosa (L.) Spreng., Calophyllum inophyllum L., Hibiscus tiliaceus L., Ficus tinctoria Fort. f., and Pandanus japensis Mart.

General information about geology, soils, forest types, and climate of Guam and Rota is similar as they are separated by ca. $60 \mathrm{~km}[5,9,10,12]$. The tropical marine climate is benign and it is characterized with daily minimum temperatures ranging from $23-25{ }^{\circ} \mathrm{C}$ and daily maximum temperatures ranging from $29-31^{\circ} \mathrm{C}$. Yearly rainfall is about $2500 \mathrm{~mm}$, with about 55 percent occurring during the rainy season from Jul to Nov. The geological history and soils of Yap are dissimilar from that of Guam and Rota, but the tropical climate is similar [11,13]. Daily minimum temperatures ranging from $23-24{ }^{\circ} \mathrm{C}$ and daily maximum temperatures ranging from $30-31{ }^{\circ} \mathrm{C}$. Yearly annual rainfall is $3050 \mathrm{~mm}$, and even the driest month of Feb averages $146 \mathrm{~mm}$ of precipitation.

Guam $\left(13.4^{\circ} \mathrm{N}\right)$ and Rota $\left(14.1^{\circ} \mathrm{N}\right)$ are positioned at in the most active tropical cyclone basin worldwide [14], and these frequent violent storms deposit copious amounts of green plant tissues on the litter layer. Yap $\left(9.5^{\circ} \mathrm{N}\right)$ is positioned at the southern edge of the tropical cyclone belt, so the frequency of these disturbances is minimal when compared to Guam and Rota.

\subsection{Field Sampling}

Within each habitat, 12 large C. micronesica trees greater than $3 \mathrm{~m}$ in stem height were selected as "target" sites. The height of each target tree was measured, then soil was harvested from the $0-15 \mathrm{~cm}$ zone while using a fixed pattern. The target soils were collected at the four cardinal points at distances of $1 \mathrm{~m}$ from the stem and at the leaf canopy drip line. Maximum C. micronesica leaf length is approximately $2 \mathrm{~m}$, so this provided eight soil cores that were homogenized to represent soil status underneath the umbrella of influence of the C. micronesica trees. The "non-target" sites were defined by a ring of $5 \mathrm{~m}$ radius surrounding each target tree, and eight soil samples were obtained at the four cardinal points and the four intercardinal points. Due to the plant density, some of these prescribed sampling sites were in close proximity with other $C$. micronesica trees. In these cases, more distance from the target tree was added to ensure a distance of at least four meters from other $C$. micronesica trees. The eight non-target soil samples were homogenized into one sample. 


\subsection{Analyses}

Total carbon $(\mathrm{C})$ and nitrogen $(\mathrm{N})$ contents were determined by dry combustion (FLASH EA1112 CHN analyzer; Thermo Fisher, Waltham, MA, USA). Extractable essential nutrients other than phosphorus $(\mathrm{P})$ were quantified following digestion with diethylenetriaminepentaacetic acid, and total metals were quantified following digestion with nitric acid $[15,16]$. Analysis was by inductively coupled plasma optical emission spectrometry (Spectro Genesis; SPECTRO Analytical Instruments, Kleve, Germany). The available P was determined by the Olsen method [17] for alkaline soils and modified Truog method [18] for acid soils.

\subsection{Statistics}

Variables that met parametric requirements were subjected to paired $t$ test to determine differences between target and non-target soils (SAS 9.3; SAS Institute, Cary, IN, USA). The stoichiometric variables $\mathrm{C} / \mathrm{N}, \mathrm{C} / \mathrm{P}$, and N/P were log-transformed prior to analysis. Some of the rare metals were undetected in some of the replications, and in these cases, no transformations were able to satisfy parametric requirements. For these metals, the Mann-Whitney $U$ test [19] was used, as this test does not require any assumption about distribution of the data.

\section{Results}

The target soils beneath $C$. micronesica trees (height $=367 \pm 22 \mathrm{~cm}$, mean $\pm \mathrm{SE}$ ) differed from the meta-community non-target soils in most C:N:P traits in Guam cobbly clay soils (Figure 2. Target soils were $27 \%$ greater in $\mathrm{N}(t=0.28, p=0.011)$ and $25 \%$ less in $\mathrm{P}(t=3.30, p=0.003)$ than non-target soils. Target soils were $14 \%$ less in $\mathrm{C} / \mathrm{N}(t=2.12, p=0.046), 29 \%$ greater in $\mathrm{C} / \mathrm{P}(t=3.80, p=0.001)$, and $22 \%$ greater in $\mathrm{N} / \mathrm{P}(t=5.37, p<0.001)$ than non-target soils.

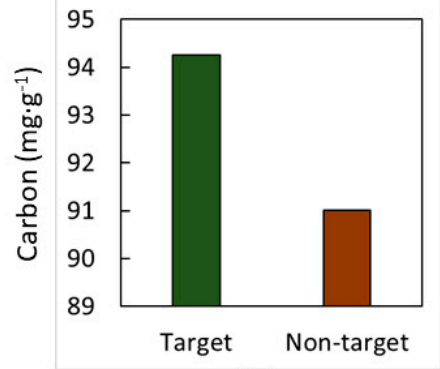

(a)

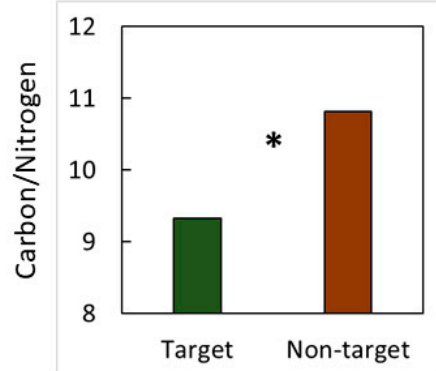

(d)

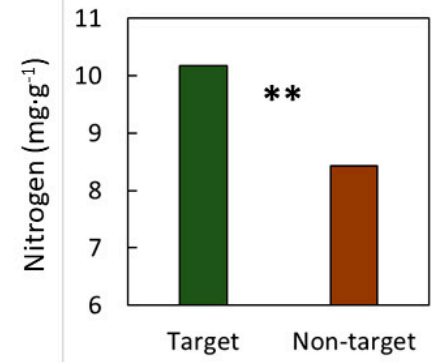

(b)

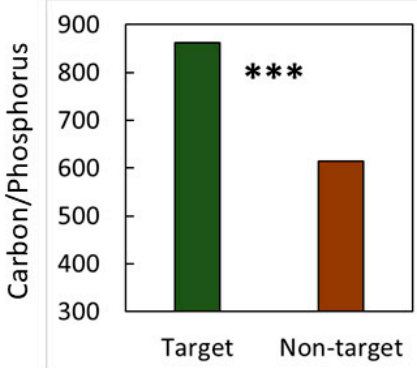

(e)

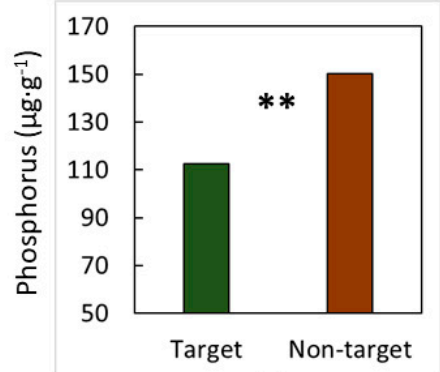

(c)

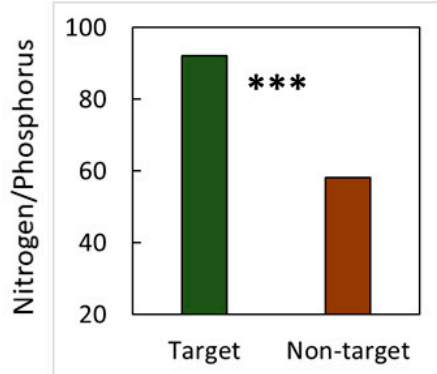

(f)

Figure 2. The influence of proximity to Cycas micronesica on soil chemical traits in Guam cobbly clay soils on Guam. Target soils were collected underneath cycad trees. Non-target soils were collected 5-m from focal cycad trees. (a) Total carbon; (b) Total nitrogen; (c) Olsen phosphorus; (d) Carbon/nitrogen;

(e) Carbon/phosphorus; and, (f) Nitrogen/phosphorus. ${ }^{*}, * *, * * *$ significant at $0.05,0.01$, or 0.001 .

With the exception of Magnesium (Mg), which decreased 10\% in target soils as compared with non-target soils, the remainder of minerals and metals were unaffected by the presence of $C$. micronesica trees in this Guam soil (Table 1). Arsenic (As) was not detected in any of the sites. 
Table 1. The influence of proximity to Cycas micronesica trees on soil chemical traits in Guam cobbly clay soils on Guam. Target soils were collected underneath cycad trees. Non-target soils were collected 5 -m from focal cycad trees. Means $\pm \mathrm{SE}, n=12$.

\begin{tabular}{ccccc}
\hline Soil trait & Target & Non-Target & Statistic $^{\mathbf{1}}$ & Significance \\
\hline $\mathrm{pH}$ & $7.4 \pm 0.1$ & $7.3 \pm 0.1$ & $t=0.40$ & 0.697 \\
Potassium $^{2}$ & $342.7 \pm 28.8$ & $469.6 \pm 58.3$ & $t=1.95$ & 0.064 \\
Calcium $^{2}$ & $10,349.5 \pm 625.7$ & $10,133.3 \pm 676.0$ & $t=0.24$ & 0.817 \\
Magnesium $^{2}$ & $881.8 \pm 27.2$ & $980.8 \pm 40.0$ & $t=2.28$ & 0.033 \\
Manganese $^{2}$ & $55.1 \pm 4.3$ & $60.5 \pm 5.9$ & $t=0.60$ & 0.552 \\
Iron $^{2}$ & $36.1 \pm 2.5$ & $39.4 \pm 2.1$ & $t=0.99$ & 0.330 \\
Cadmium $^{3}$ & $6.2 \pm 0.3$ & $5.6 \pm 0.2$ & $t=0.95$ & 0.353 \\
Cobalt $^{3}$ & $20.3 \pm 1.2$ & $21.0 \pm 1.7$ & $t=0.35$ & 0.728 \\
Chromium $^{3}$ & $102.4 \pm 9.0$ & $96.9 \pm 9.3$ & $t=0.42$ & 0.682 \\
Copper $^{3}$ & $77.4 \pm 3.2$ & $82.6 \pm 5.9$ & $t=0.77$ & 0.448 \\
Nickel $^{3}$ & $17.5 \pm 1.1$ & $16.0 \pm 1.2$ & $t=0.91$ & 0.371 \\
Lead $^{3}$ & $3.1 \pm 2.1$ & $3.0 \pm 2.0$ & $U=72$ & 0.976 \\
Selenium $^{3}$ & $0.5 \pm 0.2$ & $0.3 \pm 0.1$ & $U=63$ & 0.603 \\
Zinc $^{3}$ & $105.8 \pm 8.7$ & $109.4 \pm 8.6$ & $t=0.29$ & 0.774
\end{tabular}

${ }^{1}$ Mann-Whitney $U$ test, or standard $t$ test. ${ }^{2}$ diethylenetriaminepentaacetic acid extractable, $\mu \mathrm{g} \cdot \mathrm{g}^{-1} \cdot{ }^{3}$ nitric acid digestible, $\mu \mathrm{g} \cdot \mathrm{g}^{-1}$.

Guam's acid volcanic soils were changed to a greater degree by the presence of $C$. micronesica trees (height $=343 \pm 19 \mathrm{~cm}$ ) than were the alkaline soils (Figure 3 Table 2). Target soils exhibited a 13-fold increase in $C(t=53.18, p<0.0001)$, an $83 \%$ increase in $\mathrm{N}(t=26.32, p<0.0001)$, and a $13 \%$ decrease in $\mathrm{P}(t=4.41, p<0.001)$ when compared with thenon-target soils. Target soils were $14 \%$ greater in $\mathrm{C} / \mathrm{N}(t=20.46, p<0.001), 93 \%$ greater in $\mathrm{C} / \mathrm{P}(t=79.58, p<0.0001)$, and $85 \%$ greater in $\mathrm{N} / \mathrm{P}(t=39.98$, $p<0.001)$ than the non-target soils.

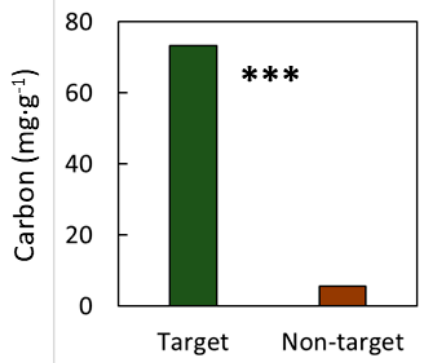

(a)

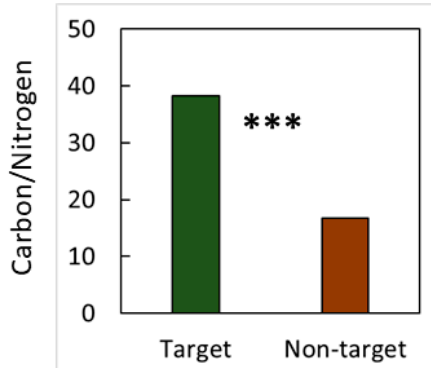

(d)

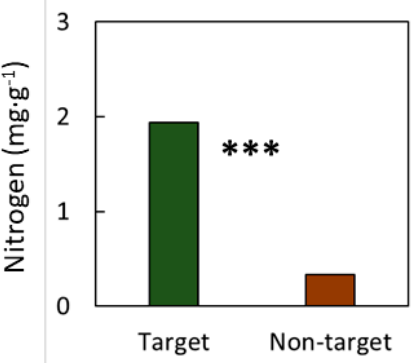

(b)

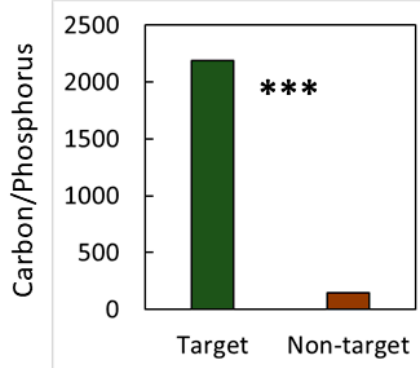

(e)

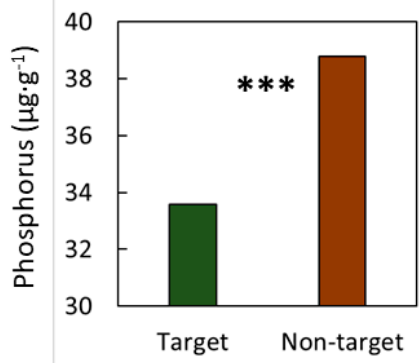

(c)

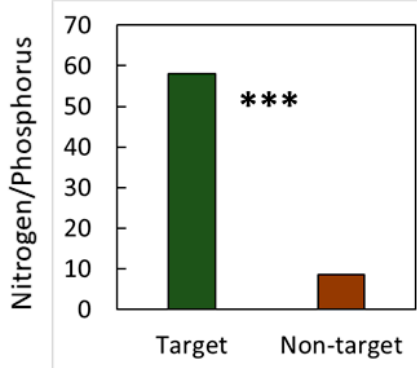

(f)

Figure 3. The influence of proximity to Cycas micronesica on soil chemical traits in Akina soils on Guam. Target soils were collected underneath cycad trees. Non-target soils were collected 5-m from focal cycad trees. (a) Total carbon; (b) Total nitrogen; (c) Modified Truog phosphorus; (d) Carbon/nitrogen; (e) Carbon/phosphorus; and, (f) Nitrogen/phosphorus. ${ }^{* * *}=$ significant at 0.001 . 
Table 2. The influence of proximity to Cycas micronesica trees on soil chemical traits in Akina soils on Guam. Target soils were collected underneath cycad trees. Non-target soils were collected 5-m from focal cycad trees. Means $\pm \mathrm{SE}, n=12$.

\begin{tabular}{ccccc}
\hline Soil Trait & Target & Non-Target & Statistic $^{\mathbf{1}}$ & Significance \\
\hline $\mathrm{pH}$ & $6.8 \pm 0.0$ & $6.3 \pm 0.1$ & $t=5.54$ & $<0.001$ \\
Potassium $^{2}$ & $1778.0 \pm 21.1$ & $1918.3 \pm 36.4$ & $t=3.34$ & 0.003 \\
Calcium $^{2}$ & $7957.7 \pm 67.5$ & $5846.5 \pm 78.4$ & $t=20.42$ & $<0.001$ \\
Magnesium $^{2}$ & $2945.9 \pm 15.3$ & $3293.3 \pm 115.2$ & $t=2.99$ & 0.007 \\
Manganese $^{2}$ & $31.8 \pm 1.8$ & $55.1 \pm 1.2$ & $t=10.87$ & $<0.001$ \\
Iron $^{2}$ & $49.9 \pm 1.6$ & $95.9 \pm 2.1$ & $t=17.37$ & $<0.001$ \\
Cobalt $^{3}$ & $23.5 \pm 1.0$ & $17.0 \pm 1.0$ & $t=5.81$ & $<0.001$ \\
Chromium $^{3}$ & $10.9 \pm 0.8$ & $12.0 \pm 0.8$ & $t=1.05$ & 0.304 \\
Copper $^{3}$ & $78.3 \pm 1.8$ & $80.0 \pm 3.8$ & $t=0.41$ & 0.344 \\
Nickel $^{3}$ & $9.3 \pm 0.7$ & $7.3 \pm 0.9$ & $t=1.74$ & 0.096 \\
Selenium $^{3}$ & $0.2 \pm 0.0$ & $0.1 \pm 0.0$ & $U=29$ & 0.014 \\
Zinc $^{3}$ & $60.6 \pm 0.9$ & $98.2 \pm 2.4$ & $t=14.48$ & $<0.001$ \\
\hline
\end{tabular}

${ }^{1}$ Mann-Whitney $U$ test, or standard $t$ test. ${ }^{2}$ diethylenetriaminepentaacetic acid extractable, $\mu \mathrm{g} \cdot \mathrm{g}^{-1} \cdot{ }^{3}$ nitric acid digestible, $\mu \mathrm{g} \cdot \mathrm{g}^{-1}$.

The acid target soils were decreased in potassium $(\mathrm{K}), \mathrm{Mg}$, manganese $(\mathrm{Mn})$, iron $(\mathrm{Fe})$, and zinc ( $\mathrm{Zn})$ (Table 2). The target soils were increased in $\mathrm{pH}$, calcium (Ca), cobalt (Co), and selenium (Se) when compared with the non-target soils. Lead $(\mathrm{Pb})$ and As were not detected in any of the soils.

Guam's karst soils were changed to a similar degree by the presence of $C$. micronesica trees (height $=335 \pm 15 \mathrm{~cm}$ ), as were Guam's alkaline soils (Figure 4, Table 3). Target soils increased 26\% in $\mathrm{N}(t=5.17, p<0.0001)$, decreased $24 \%$ in $\mathrm{C} / \mathrm{N}(t=2.77, p=0.011)$, and increased $42 \%$ in $\mathrm{N} / \mathrm{P}(t=3.45$, $p=0.002)$ when compared with the non-target soils. The remainder of the quantified minerals and metals were unaffected by the presence of $C$. micronesica trees. Cadmium (Cd), $\mathrm{As}$, and $\mathrm{Pb}$ were not detected in any of the soils.

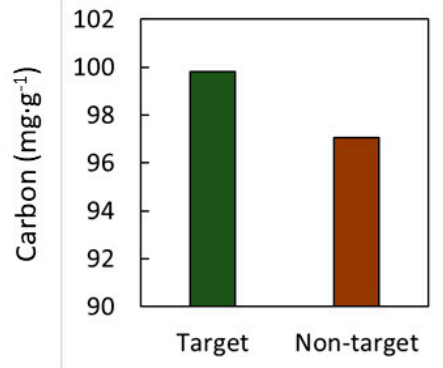

(a)

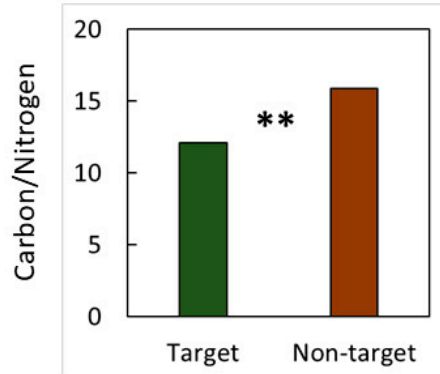

(d)

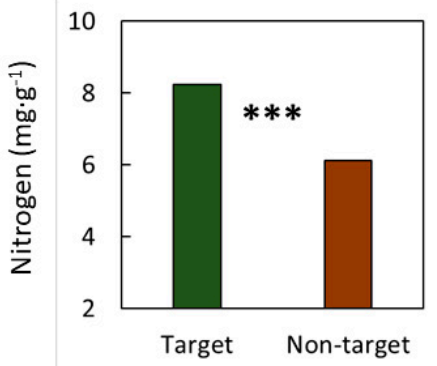

(b)

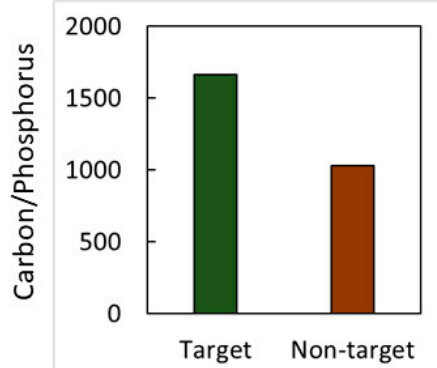

(e)

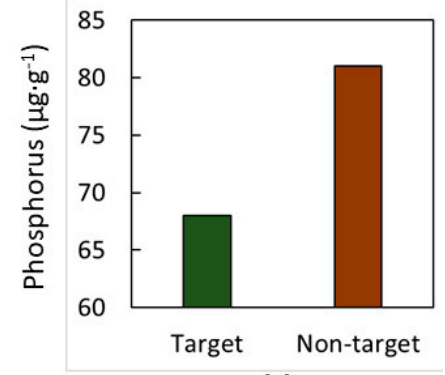

(c)

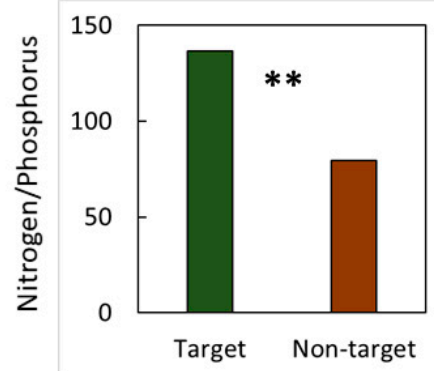

(f)

Figure 4. The influence of proximity to Cycas micronesica on soil chemical traits in Ritidian Rock Outcrop soils on Guam. Target soils were collected underneath cycad trees. Non-target soils were collected 5-m from focal cycad trees. (a) Total carbon; (b) Total nitrogen; (c) Olsen phosphorus; (d) Carbon/nitrogen; (e) Carbon/phosphorus; and, (f) Nitrogen/phosphorus. ${ }^{* *},{ }^{* * *}=$ significant at 0.01 or 0.001 . 
Table 3. The influence of proximity to Cycas micronesica trees on soil chemical traits in Ritidian Rock Outcrop soils on Guam. Target soils were collected underneath cycad trees. Non-target soils were collected 5-m from focal cycad trees. Means \pm SE, $n=12$.

\begin{tabular}{ccccc}
\hline Soil Trait & Target & Non-Target & Statistic $^{\mathbf{1}}$ & Significance \\
\hline $\mathrm{pH}$ & $7.5 \pm 0.1$ & $7.4 \pm 0.1$ & $t=0.32$ & 0.752 \\
Potassium $^{2}$ & $298.3 \pm 19.8$ & $3551 \pm 28.1$ & $t=1.64$ & 0.114 \\
Calcium $^{2}$ & $8983.2 \pm 666.3$ & $8632.8 \pm 638.3$ & $t=0.38$ & 0.708 \\
Magnesium $^{2}$ & $758.7 \pm 31.0$ & $827.2 \pm 43.3$ & $t=1.28$ & 0.212 \\
Manganese $^{2}$ & $61.5 \pm 6.0$ & $79.7 \pm 9.4$ & $t=1.63$ & 0.118 \\
Iron $^{2}$ & $46.2 \pm 3.1$ & $54.0 \pm 5.1$ & $t=1.33$ & 0.197 \\
Cadmium $^{3}$ & $5.8 \pm 0.4$ & $5.7 \pm 0.4$ & $t=0.23$ & 0.821 \\
Cobalt $^{3}$ & $20.6 \pm 1.5$ & $21.4 \pm 1.5$ & $t=0.42$ & 0.676 \\
Chromium $^{3}$ & $105.0 \pm 11.6$ & $105.2 \pm 10.7$ & $t=0.01$ & 0.992 \\
Copper $^{3}$ & $7500 \pm 2.4$ & $81.2 \pm 4.00$ & $t=1.33$ & 0.196 \\
Nickel $^{3}$ & $19.3 \pm 2.0$ & $18.3 \pm 1.5$ & $t=0.41$ & 0.684 \\
Lead $^{3}$ & $3.4 \pm 3.4$ & $9.6 \pm 7.6$ & $U=72$ & 0.999 \\
Selenium $^{3}$ & $0.4 \pm 0.2$ & $0.3 \pm 0.2$ & $U=72$ & 0.976 \\
Zinc $^{3}$ & $88.9 \pm 6.8$ & $90.7 \pm 5.9$ & $t=0.19$ & 0.850 \\
\hline
\end{tabular}

${ }^{1}$ Mann-Whitney $U$ test, or standard $t$ test. ${ }^{2}$ diethylenetriaminepentaacetic acid extractable, $\mu \mathrm{g} \cdot \mathrm{g}^{-1} \cdot{ }^{3}$ nitric acid digestible, $\mu \mathrm{g} \cdot \mathrm{g}^{-1}$.

The sandy littoral soils from Rota were changed to a greater degree by the presence of $C$. micronesica trees (height $=345 \pm 15 \mathrm{~cm}$ ) than were Guam's alkaline soils (Figure 5, Table 4). Target soils exhibited a $36 \%$ increase in $\mathrm{N}(t=2.43, p=0.024)$ and a $21 \%$ decrease in $\mathrm{P}(t=2.57, p=0.017)$ when compared with non-target soils. Target soils were $43 \%$ less in $\mathrm{C} / \mathrm{N}(t=3.14, p=0.005), 28 \%$ greater in $\mathrm{C} / \mathrm{P}$ $(t=7.12, p<0.0001)$, and $52 \%$ greater in N/P $(t=6.30, p<0.001)$ than the non-target soils. More of the soil metals were influenced by the long-term presence of $C$. micronesica trees than were the minerals. Target soils were greater in cobalt (Co), $\mathrm{Cr}$, and selenium (Se), and lower in iron (Fe), $\mathrm{Cd}$, and $\mathrm{Pb}$ than non-target soils. None of the sandy soils contained Copper $(\mathrm{Cu})$ or nickel $(\mathrm{Ni})$.

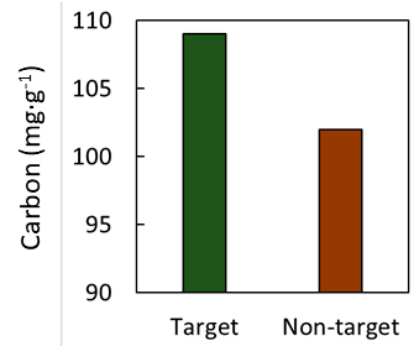

(a)

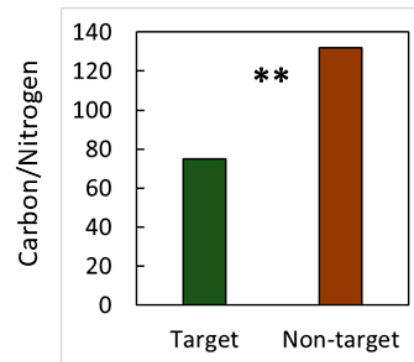

(d)

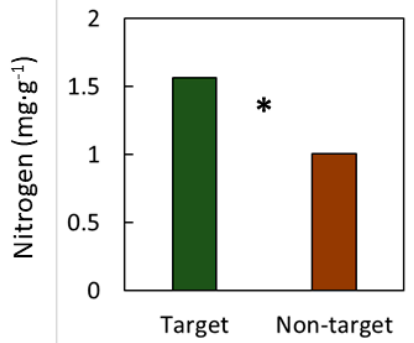

(b)

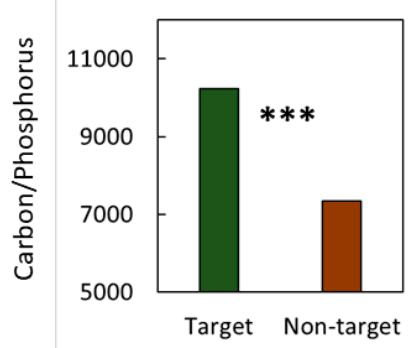

(e)

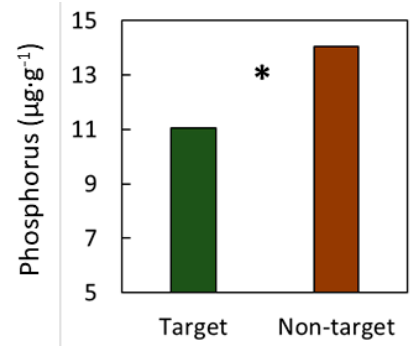

(c)

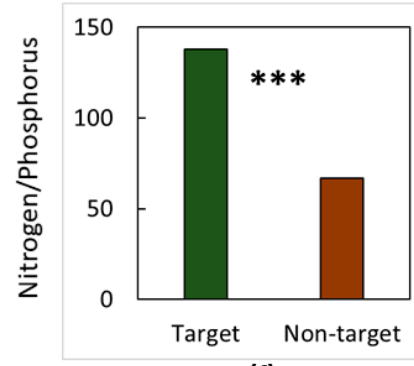

(f)

Figure 5. The influence of proximity to Cycas micronesica on soil chemical traits in Shioya sand soils on Rota. Target soils were collected underneath cycad trees. Non-target soils were collected 5-m from focal cycad trees. (a) Total carbon; (b) Total nitrogen; (c) Olsen phosphorus; (d) Carbon/nitrogen; (e) Carbon/phosphorus; and, (f) Nitrogen/phosphorus. ${ }^{*}, * *, * * *$ significant at $0.05,0.01$, or 0.001 . 
Table 4. The influence of proximity to Cycas micronesica trees on soil chemical traits in Shioya sand soils on Rota. Target soils were collected underneath cycad trees. Non-target soils were collected 5-m from focal cycad trees. Means $\pm \mathrm{SE}, n=12$.

\begin{tabular}{|c|c|c|c|c|}
\hline Soil Trait & Target & Non-Target & Statistic ${ }^{1}$ & Significance \\
\hline $\mathrm{pH}$ & $7.9 \pm 0.0$ & $8.0 \pm 0.0$ & $t=2.43$ & 0.024 \\
\hline Potassium $^{2}$ & $21.1 \pm 3.1$ & $38.9 \pm 6.0$ & $t=2.64$ & 0.015 \\
\hline Calcium $^{2}$ & $9525.5 \pm 222.8$ & $9044.4 \pm 235.6$ & $t=1.18$ & 0.253 \\
\hline Magnesium ${ }^{2}$ & $470.2 \pm 30.9$ & $404.8 \pm 19.1$ & $t=1.80$ & 0.086 \\
\hline Manganese 2 & $18.5 \pm 0.8$ & $17.7 \pm 1.3$ & $t=1.54$ & 0.138 \\
\hline Iron $^{2}$ & $5.7 \pm 0.4$ & $6.9 \pm 0.3$ & $t=2.22$ & 0.037 \\
\hline Arsenic $^{3}$ & $0.3 \pm 0.0$ & $0.2 \pm 0.1$ & $t=1.09$ & 0.287 \\
\hline Cadmium $^{3}$ & $0.1 \pm 0.0 .0$ & $0.1 \pm 0.0$ & $t=4.01$ & 0.001 \\
\hline Cobalt $^{3}$ & $0.2 \pm 0.0$ & $0.1 \pm 0.0$ & $t=5.60$ & $<0.001$ \\
\hline Copper $^{3}$ & $0.4 \pm 0.0$ & $0.3 \pm 0.0$ & $t=2.41$ & 0.025 \\
\hline Chromium $^{3}$ & $3.9 \pm 0.3$ & $2.4 \pm 0.1$ & $t=4.73$ & $<0.001$ \\
\hline Lead $^{3}$ & $0.1 \pm 0.0$ & $0.4 \pm 0.1$ & $t=3.72$ & 0.001 \\
\hline Selenium $^{3}$ & $3.5 \pm 0.0$ & $3.0 \pm 0.0$ & $t=13.82$ & $<0.001$ \\
\hline Zinc $^{3}$ & $10.6 \pm 1.5$ & $7.5 \pm 1.1$ & $t=1.73$ & 0.097 \\
\hline
\end{tabular}

Yap's schist soils were changed to a similar degree by the presence of $C$. micronesica trees (height $=353 \pm 16 \mathrm{~cm}$ ) as were Guam's acid soils (Figure 6, Table 5). Target soils exhibited a 40\% increase in $C(t=7.17, p<0.0001)$, an $42 \%$ increase in $\mathrm{N}(t=4.63, p<0.0001)$, and a $21 \%$ decrease in $\mathrm{P}$ $(t=4.41, p<0.001)$ when compared with the non-target soils. Target soils were $49 \%$ greater in $\mathrm{C} / \mathrm{P}$ $(t=5.68, p<0.0001)$, and $51 \%$ greater in $\mathrm{N} / \mathrm{P}(t=4.48, p<0.001)$ than the non-target soils. Target soils were greater in $\mathrm{Ca}, \mathrm{Mg}, \mathrm{Mn}$, and $\mathrm{Cu}$; and, lower in $\mathrm{K}$ and $\mathrm{Co}$ non-target soils. None of the sandy soils contained $\mathrm{As}, \mathrm{Cd}$, or $\mathrm{Pb}$.

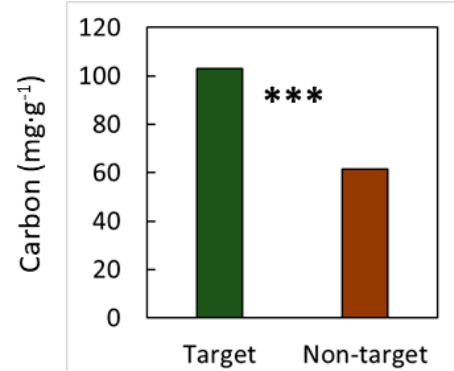

(a)

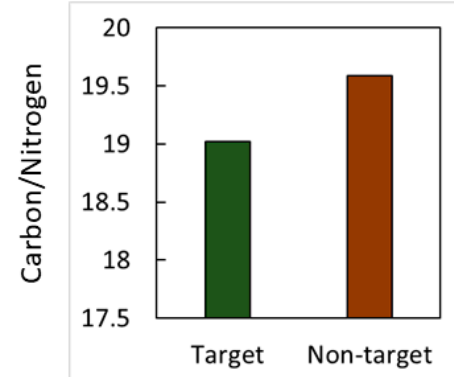

(d)

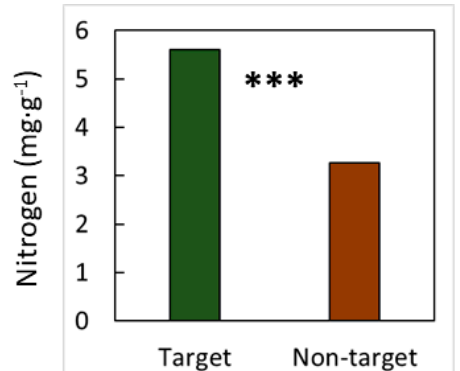

(b)

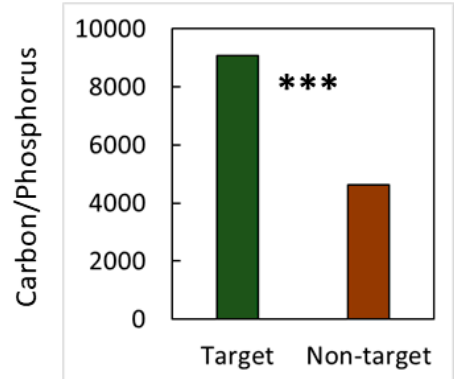

(e)

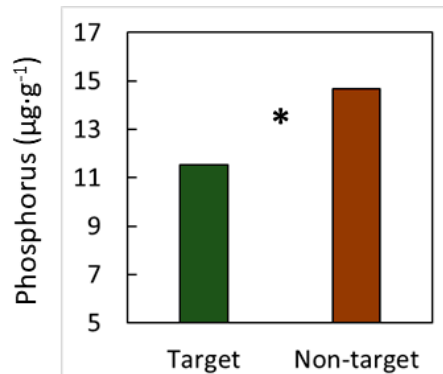

(c)

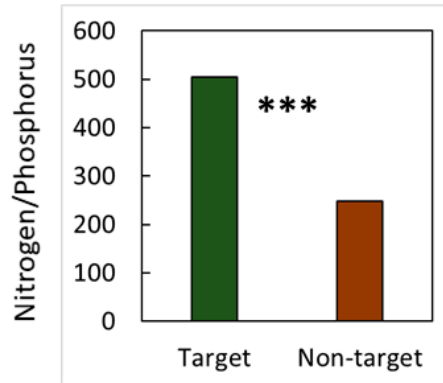

(f)

Figure 6. The influence of proximity to Cycas micronesica on soil chemical traits in schist soils on Yap. Target soils were collected underneath cycad trees. Non-target soils were collected 5-m from focal cycad trees. (a) Total carbon; (b) Total nitrogen; (c) Modified Truog phosphorus; (d) Carbon/nitrogen; (e) Carbon/phosphorus; and, (f) Nitrogen/phosphorus. ${ }^{*},{ }^{* *},{ }^{* *}=$ significant at $0.05,0.01$, or 0.001 . 
Table 5. The influence of proximity to Cycas micronesica trees on soil chemical traits in schist soils on Yap. Target soils were collected underneath cycad trees. Non-target soils were collected 5-m from focal cycad trees. Means $\pm \mathrm{SE}, n=12$.

\begin{tabular}{ccccc}
\hline Soil Trait & Target & Non-Target & Statistic ${ }^{1}$ & Significance \\
\hline pH & $5.9 \pm 0.2$ & $5.7 \pm 0.1$ & $t=2.03$ & 0.055 \\
Potassium $^{2}$ & $91.3 \pm 10.0$ & $120.5 \pm 22.4$ & $t=2.91$ & 0.043 \\
Calcium $^{2}$ & $2012.5 \pm 417.5$ & $1212.2 \pm 174.2$ & $t=4.33$ & $<0.001$ \\
Magnesium $^{2}$ & $1031.0 \pm 214.1$ & $1367.1 \pm 203.1$ & $t=2.28$ & 0.033 \\
Manganese $^{2}$ & $11.7 \pm 2.3$ & $14.2 \pm 2.8$ & $t=2.79$ & 0.011 \\
Iron $^{2}$ & $329.2 \pm 72.4$ & $359.7 \pm 41.8$ & $t=0.89$ & 0.381 \\
Cobalt $^{3}$ & $31.5 \pm 3.0$ & $26.2 \pm 2.2$ & $t=3.41$ & 0.003 \\
Chromium $^{3}$ & $521.6 \pm 28.3$ & $545.8 \pm 75.5$ & $t=0.74$ & 0.469 \\
Copper $^{3}$ & $38.2 \pm 4.5$ & $49.8 \pm 6.9$ & $t=3.44$ & 0.002 \\
Nickel $^{3}$ & $231.1 \pm 14.6$ & $244.5 \pm 28.9$ & $t=1.02$ & 0.321 \\
Selenium $^{3}$ & $0.5 \pm 0.3$ & $0.5 \pm 0.5$ & $U=60$ & 0.509 \\
Zinc $^{3}$ & $43.8 \pm 12.1$ & $41.7 \pm 6.2$ & $t=0.37$ & 0.713 \\
\hline
\end{tabular}

${ }_{1}^{1} \overline{\text { Mann-Whitney } U \text { test, or standard } t \text { test. }{ }^{2} \text { diethylenetriaminepentaacetic acid extractable, } \mu \mathrm{g} \cdot \mathrm{g}^{-1} \cdot{ }^{3} \text { nitric acid }}$ digestible, $\mu \mathrm{g} \cdot \mathrm{g}^{-1}$.

\section{Discussion}

\subsection{The Soils}

The variation in non-target soil chemistry among the five habitats was substantial. The ability of $C$. micronesica to establish high density populations in such a range of soil types is evidence of the adaptability of the species. The two acid soils behaved similarly with regard to the influence of $C$. micronesica trees, exhibiting significant increases of $\mathrm{N}, \mathrm{C}$, and $\mathrm{Ca}$ in target soils and significant decreases of $\mathrm{P}, \mathrm{K}$, and $\mathrm{Mg}$ in the target soils. The three alkaline soils were more heterogeneous with regard to the influence of $C$. micronesica trees on soil chemistry, as $\mathrm{N}$ was the only element that behaved similarly among the soils. Yap soils exhibited the lowest $\mathrm{pH}$, the lowest macronutrient concentrations, and greatest metal concentrations. These conditions enabled the $C$. micronesica trees to increase $\mathrm{N}$ in target soils to a greater degree than in any of the other soils. Interestingly, the impoverished sandy soils with a mean total metal concentration of only $19 \mu \mathrm{g} \cdot \mathrm{g}^{-1}$ exhibited differences between the target and non-target soils for more than half of the metals, but the other soils with total metal content as high as $1273 \mu \mathrm{g} \cdot \mathrm{g}^{-1}$ exhibited less influence of $C$. micronesica tree on the concentration of individual metals. The influence of legume tree species on soil chemistry has also been shown to substantially vary among soil types [20].

\subsection{The Elements}

An increase in $\mathrm{N}$ occurred in all target soils, and $\mathrm{N}$ was the only element that exhibited a consistent significant change among all of the habitats. The direction of change caused by a C. micronesica tree was homogeneous among the soils for every other element, but the level of significance was inconsistent among the soils. For example, $\mathrm{C}$ increased in every target soil, but it was not significant in the three alkaline soils. Similarly, P decreased in every target soil, but it was not significant in the karst soils.

Carbon and $\mathrm{N}$ were the only elements that the $C$. micronesica trees entirely or partially derived from non-soil outside sources (the atmosphere), so root or leaf litter decomposition released $C$ and $\mathrm{N}$ into the soil community that was not entirely recycled. The remainder of the minerals and metals were initially extracted from the local soil pools, so root or leaf litter decomposition re-released these elements as recycled soil contributions. The target soils were always higher in $\mathrm{C}$ and $\mathrm{N}$, but were lower in $\mathrm{P}$ than the non-target soils. These traits generated similar changes in $\mathrm{C} / \mathrm{P}$ and $\mathrm{N} / \mathrm{P}$ among the five soils, but heterogeneous changes in $\mathrm{C} / \mathrm{N}$ depending on which of the two elements was increased the most by the $C$. micronesica trees. 
Carbon accumulations adjacent to the C. micronesica trees may have been due to recalcitrant senesced roots and leaves in comparison to decomposing organs from the metacommunity. The diversity and volume of production of bio-platform molecules is taxon-specific, and which of those molecules journey from within the plant body to released senesced tissues is also partially under genetic control. These plant-derived molecules are often complex and therefore recalcitrant towards deconstruction. Quantifying every fraction of the standing soil $C$ pool would increase our understanding of how a cycad tree is able to increase $\mathrm{C}$ within close proximity to the unique trees.

The $\mathrm{N}$ relations of these soils may be more fully understood by calculating the relative net nitrification $(\mathrm{RNN}=$ (net nitrification) $/($ net total $\mathrm{N}$ mineralization $) \times 100)$, where net total $\mathrm{N}$ mineralization is the sum of ammonification and nitrification. RNN was $95 \%$ for the target sites and $82 \%$ for the non-target sites. Clearly, the nitrifying genera Nitrosomonas and Nitrobacter [21] were more active in the target sites and less active in the non-target sites. As with the $\mathrm{C}$ relations, more quantifications of every fraction of the $\mathrm{N}$ pool, such as organic $\mathrm{N}$, would increase our understanding of how the $\mathrm{N}$ heterogeneity that we have reported is sustained within cycad habitats.

\subsection{Informative Sub-Disciplines Literature}

The underlying mechanisms that enabled the changes in soils following long-term direct contact with a C. micronesica tree were not determined. The literature contains abundant relevant informative examples within the following three areas of research. This literature may provide appropriate methods for future experimental approaches to tease apart the plant behaviors that lead to the soil change that we have documented.

\subsubsection{Fertile Islands}

The literature on fertile islands has focused on arid and semi-arid environments where a woody plant becomes established in grassland or barren habitats. These shrubs then begin the process of creating "islands of fertility" directly beneath their canopies [22-24]. Drivers of this spatial change in soil fertility include microsite accumulation of high quality litter, nutrient inputs from enhanced animal visitations, nutrients concentrated in stemflow, unique vertical and horizontal root contributions, and increases in the mycorrhizal activities.

\subsubsection{Plant-Soil Feedback}

Plant-soil feedback is one of the mechanisms that mediates ecological succession and biodiversity coexistence. The abiotic and biotic traits of soils are changed by plants, and those changes can influence subsequent plant growth $[25,26]$. Plant-soil feedback is usually studied in the context of priming the soils by first growing one plant species, and then monitoring conspecific or heterospecific subsequent growth in the same soils. The direction of the feedback can be negative, where nutrients are immobilized or depleted or pathogens accumulate; or, can be positive, where nutrients or mutualists accumulate [27]. "Soil legacy effects" are commonly studied in the context of invasive plant species that possess the power to engineer changes in ecosystem of the invaded habitats [28]. This subset of the plant-soil feedback agenda is often invoked for discussing allelopathic properties that remain in soils following invasive plant species growth. For example, soils that persist following the widespread mortality of $C$. micronesica due to long-term $A$. yasumatsui damage often remain barren due to unidentified residuals $[29,30]$.

\subsubsection{Home-Field Advantage}

The home-field advantage hypothesis predicts that plant litter decomposes more rapidly within the vicinity of the source plant than in some distant location, because decomposers that specialize in the source litter are in greater quantity close to the source plant [31]. This heterogeneity in specialist decomposer community can have cascading effects on the heterogeneity of biogeochemical traits in the soil layer. 


\subsection{Synthesis}

A large literature has accumulated on each of these sub-disciplines, and the direct influence of the plant's presence on the microsite soil is a common thread. Controlled experimental approaches are common, but in-situ observational studies in mixed forest stands are also represented [32]. Our objectives did not include approaches to identify the mechanisms that $C$. micronesica trees employ to exert local changes in the soil traits. However, these three subsets of the ecology and restoration literature provide ample examples of experimental approaches that could be used to more fully understand how cycad plants modify their habitats. Regardless of the causal mechanisms, our results were robust and some trait changes were consistent among the many habitat and soil types. Given the considerable changes in C:N:P and other soil traits, an in-situ C. micronesica tree creates the conditions to increase $\alpha$-diversity of soil microbiota [33]. The influence of $C$. micronesica trees on the heterogeneity of soil nitrogen is of particular interest, as nitrogen availability directly affects growth of primary producers in a landscape then exerts cascading effects on food web functioning among many trophic levels [34]. Moreover, we have shown that the selective removal of this foundation species from Guam and Rota habitats by the A. yasumatsui invasion has the potential to homogenize the degraded island communities and erode soil biodiversity.

Shortly after we conducted the field work in Guam and Rota, each habitat was invaded by A. yasumatsui. More than $90 \%$ of the resident $C$. micronesica population has been subsequently killed by the invasions (unpublished data), thereby removing this important biological genesis of community heterogeneity. The community responses will likely homogenize soil chemical traits and reduce soil biodiversity. This study provides crucial quantitative baseline information $[35,36]$ that may be useful for future monitoring to determine localized biodiversity erosion in the medium term and ecological restoration attempts in the long term. Continued manipulative studies that are designed to more fully understand how C. micronesica trees behave in plant-soil feedbacks are no longer possible on Guam or Rota. However, the in-situ populations in Yap and Palau remain unthreatened, and these habitats remain available for continued research. Our information derived prior to the onset of the contemporary biological threats in Guam and Rota provides benchmark data that may enable quantifying ecological restoration goals in the future.

\subsection{Conservation}

Few reports have included green leaf tissue nutrient levels of cycad species for the purpose of increasing our understanding of cycad biology and conservation. In order to be informative, the methods of studies with these objectives need to be unambiguous and repeatable. The ionome and resulting biochemistry of sessile perennial plants is under the control of the immediate environment. The absolute levels of essential and non-essential elements and the stoichiometry among these elements within soils can affect the corresponding plant tissue contents [37,38]. The reports that include green leaf element contents of cycad species have not adequately quantified these consequential local soil traits to carry out the methods appropriately. For example, most of the papers do not include any mention of the corresponding soil nutritional status [39-42]. Other papers include generic descriptions of the soil characteristics without collecting specific experimental soil samples to improve the accuracy of the methods [43]. Other papers include soil samples from the experimental sites, but they do not indicate proximity of the samples to the studied cycad plants [44]. We are aware of only two reports that included dedicated soil sampling with descriptions of proximity to the cycad plants that were being studied for green leaf nutrient content $[45,46]$. Continued research within this agenda must include descriptions of influential soil chemistry, and our results indicate the sampling sites must be constrained within close proximity to the studied cycad plants to enable the legitimacy of the methods. 


\section{Conclusions}

The long-lived C. micronesica tree is able to modify the elemental profile of the soils within the drip line of its leaf canopy. The potential causal mechanisms that a $C$. micronesica tree employs to modify the soils in direct contact with it were not analyzed in this study. The results, however, do reveal that loss of these localized habitat modifications by the recent invasion of $A$. yasumatsui, which has killed most of the $C$. micronesica tree populations on Rota and Guam, will decrease soil chemical heterogeneity at the community level. The spatial changes in soil C:N:P and other chemical traits will then influence $\alpha$-diversity of soil microbiota and the ecological processes that these organisms modulate. This is the first report which indicates a healthy cycad tree increases soil community heterogeneity through modifications on localized soil mineral and metal concentrations. More case studies are needed to determine whether this is a common cycad trait or is variable among the other cycad species. Cycads are the most threatened plant group worldwide [47-49], and the consequences of continuing losses of cycads throughout the globe are magnified by the collateral loss of community heterogeneity. This case study also provides an example of how invasions of islands can damage ecological processes by removing the services of unique native species.

Author Contributions: Conceptualization, T.E.M. and M.V.K.; Methodology, T.E.M.; Software, T.E.M.; Formal Analysis, T.E.M.; Investigation, T.E.M. and M.V.K.; Resources, T.E.M. and M.V.K.; Data Curation, T.E.M.; Writing-Original Draft Preparation, T.E.M.; Writing-Review \& Editing, M.V.K.; Project Administration, T.E.M.; Funding Acquisition, T.E.M.

Funding: This research was funded by United States Forest Service grant numbers 06-DG-11052021-206, 09-DG-11052021-173, and 13-DG-11052021-210.

Acknowledgments: We thank Nirmala Dongol for technical support.

Conflicts of Interest: The authors declare no conflict of interest. The funders had no role in the design of the study; in the collection, analyses, or interpretation of data; in the writing of the manuscript, and in the decision to publish the results.

\section{References}

1. Hill, K.D. The Cycas rumphii complex (Cycadaceae) in New Guinea and the Western Pacific. Aust. Syst. Bot. 1994, 7, 543-567. [CrossRef]

2. Marler, T.E. Cycad aulacaspis scale invades the Mariana Islands. Mem. N. Y. Bot. Gard. 2012, 106, $20-35$.

3. Marler, T.E.; Lawrence, J.H. Demography of Cycas micronesica on Guam following introduction of the armoured scale Aulacaspis yasumatsui. J. Trop. Ecol. 2012, 28, 233-242. [CrossRef]

4. Marler, T.E.; Lawrence, J.H. Canopy and knowledge gaps when invasive alien insects remove foundation species. Commun. Integr. Biol. 2013, 6, e22331. [CrossRef] [PubMed]

5. Donnegan, J.A.; Butler, S.L.; Grabowiecki, W.; Hiserote, B.A.; Limtiaco, D. Guam's Forest Resources, 2002; Resource Bulletin PNW-RB-243; U.S. Department of Agriculture, Forest Service, Pacific Northwest Research Station: Portland, OR, USA, 2004; p. 32.

6. Norstog, K.J.; Nicholls, T.J. The Biology of the Cycads; Cornell University Press: Ithica, NY, USA, 1997.

7. Brenner, E.D.; Stevenson, D.W.; Twigg, R.W. Cycads: Evolutionary innovations and the role of plant-derived neurotoxins. Trends Plant Sci. 2003, 8, 446-452. [CrossRef]

8. Marler, T.E.; Dongol, N. Three invasive insects alter Cycas micronesica leaf chemistry and predict changes in biogeochemical cycling. Commun. Integr. Biol. 2016, 9, e1208324. [CrossRef] [PubMed]

9. Young, F.J. Soil Survey of Territory of Guam. U.S. Department of Agriculture, Soil Conservation Service: Washington DC, USA, 1988.

10. Young, F.J. Soil Survey of the Islands of Aguijan, Rota, Saipan, and Tinian, Commonwealth of the Northern Mariana Islands; U.S. Department of Agriculture, Soil Conservation Service: Washington DC, USA, 1989.

11. Smith, C.W. Soil Survey of Islands of Yap Federated States of Micronesia; Department of Agriculture, Soil Conservation Service: Washington DC, USA, 1883.

12. Donnegan, J.A.; Butler, S.L.; Kuegler, O.; Hiserote, B.A. Commonwealth of the Northern Mariana Islands' Forest Resources, 2004; Resource Bulleti PNW-RB-261; U.S. Department of Agriculture, Forest Service, Pacific Northwest Research Station: Portland, OR, USA, 2011; p. 40. 
13. Falanruw, M.C.; Whitesell, C.D.; Cole, T.G.; MacLean, C.D.; Ambacher, A.H. Vegetation Survey of Yap, Federated States of Micronesia; Resourc. Bull. PSW-21; U.S. Department of Agriculture, Forest Service, Pacific Southwest Forest and Range Experiment Station: Berkeley, OR, USA, 1987; p. 9.

14. Marler, T.E. Pacific island tropical cyclones are more frequent and globally relevant, yet less studied. Front. Environ. Sci. 2014, 2, 42. [CrossRef]

15. Berghage, R.D.; Krauskopf, D.M.; Warncke, D.D.; Widders, I. Micronutrient testing of plant growth media extractant, identification and evaluation. Commun. Soil Sci. Plant Anal. 1987, 18, 1089-1109. [CrossRef]

16. Zheljazkov, V.D.; Warman, P.R. Comparison of three digestion methods for the recovery of 17 plant essential nutrients and trace elements from six composts. Compost Sci. Utiliz. 2002, 10, 197-203. [CrossRef]

17. Olsen, S.R.; Cole, C.V.; Watanabe, F.S.; Dean, L.A. Estimation of Available Phosphorus in Soils by Extraction with Sodium Bicarbonate; U.S. Department of Agriculture: Washington, DC, USA, 1954; p. 939.

18. Hue, N.V.; Ikawa, H.; Huang, X. Predicting soil phosphorus requirements. In Plant Nutrient Management in Hawaii's Soils, Approaches for Tropical and Subtropical Agriculture; Silva, J.A., Uchida, R., Eds.; College of Tropical Agriculture and Human Resources, University of Hawaii at Manoa: Honolulu, HI, USA, 2000; pp. 95-99.

19. Mann, H.B.; Whitney, D.R. On a test of whether one of two random variables is stochastically larger than the other. Ann. Math. Stat. 1947, 18, 50-60. [CrossRef]

20. Chimphango, S.B.M.; Potgieter, G.; Cramer, M.D. Differentiation of the biogeochemical niches of legumes and non-legumes in the Cape Floristic Region of South Africa. Plant Ecol. 2015, 216, 1583-1595. [CrossRef]

21. Smil, V. Cycles of Life: Civilization and the Biosphere; W.H. Freeman \& Co.: New York, NY, USA, 2000.

22. García-Moya, E.; Mckell, C.M. Contribution of shrubs to the nitrogen economy of a desert-wash plant community. Ecology 1970, 51, 81-88. [CrossRef]

23. Garner, W.; Steinberger, Y. A proposed mechanism for the formation of 'Fertile Islands' in the desert ecosystem. J. Arid Environ. 1989, 16, 257-262.

24. Carmargo-Ricalde, S.L.; Dhillion, S.S. Endemic Mimosa sp. serve as mycorrhizal "resource islands" within semiarid communities of the Tehuacán-Cuacatlán Valley, Mexico. Mycorrhiza 2003, 13, 129-136. [CrossRef] [PubMed]

25. Ehrenfeld, J.G.; Ravit, B.; Elgersma, K. Feedback in the plant soil system. Annu. Rev. Environ. Resour. 2005, 30, 75-115. [CrossRef]

26. Van der Putten, W.H.; Bardgett, R.D.; Bever, J.D.; Bezemer, T.M.; Casper, B.B.; Fukami, T.; Kardol, P.; Klironomos, J.N.; Kulmatiski, A.; Schweitzer, J.A.; et al. Plant-soil feedbacks: The past, the present and future challenges. J. Ecol. 2013, 101, 265-276. [CrossRef]

27. Kulmatiski, A.; Beard, K.H.; Stevens, J.R.; Cobbold, S.M. Plant soil feedbacks: A meta-analytical review. Ecol. Lett. 2008, 11, 980-992. [CrossRef] [PubMed]

28. Nsikani, M.M.; van Wilgen, B.W.; Gaertner, M. Barriers to ecosystem restoration presented by soil legacy effects of invasive alien $\mathrm{N}_{2}$-fixing woody species: Implications for ecological restoration. Restor. Ecol. 2018, 26, 235-244. [CrossRef]

29. Marler, T.E.; Dongol, N. Do phytotoxic compounds in soils after scale-infested Cycas micronesica litter deposits explain reduced plant growth? HortScience 2013, 48, 1571-1573.

30. Watson, G.W.; Marler, T.E. Does cycad aulacaspis scale (Aulacaspis yasumatsui, Hemiptera: Diaspididae) play a direct role in causing soil phytotoxicity? Commun. Integr. Biol. 2014, 7, e278811-e278813. [CrossRef] [PubMed]

31. Veen, G.F.; Freschet, G.T.; Ordonez, A.; Wardle, D.A. Litter quality and environmental controls of home-field advantage effects on litter decomposition. Oikos 2015, 124, 187-195. [CrossRef]

32. Pelletier, B.; Fyles, J.W.; Dutilleul, P. Tree species control and spatial structure of forest floor properties in a mixed-species stand. Ecoscience 1999, 6, 79-91. [CrossRef]

33. Tian, J.; He, N.; Hale, L.; Niu, S.; Yu, G.; Liu, Y.; Blagodatskaya, E.; Kuzyakov, Y.; Gao, Q.; Zhou, J. Soil organic matter availability and climate drive latitudinal patterns in bacterial diversity from tropical to cold temperate forests. Funct. Ecol. 2018, 32, 61-70. [CrossRef]

34. Meunier, C.L.; Gundale, M.J.; Sanchez, I.S.; Liess, A. Impact of nitrogen deposition on forest and lake food webs in nitrogen-limited environments. Glob. Chang. Biol. 2016, 22, 164-179. [CrossRef] [PubMed] 
35. Schmeller, D.S.; Böhm, M.; Arvanitidis, C.; Barber-Meyer, S.; Brummitt, N.; Chandler, M.; Eva, C.; Mark, J.C.; Hui, D.; Jaime, G.-M.; et al. Building capacity in biodiversity monitoring at the global scale. Biodiv. Cons. 2017, 26, 2765-2790. [CrossRef]

36. Borges, P.A.V.; Cardoso, P.; Kreft, H.; Whittaker, R.J.; Fattorini, S.; Emerson, B.C.; Artur, G.; Rosemary, G.G.; Thomas, J.M.; Santos, A.M.C.; et al. Global island monitoring scheme (GIMS): A proposal for the long-term coordinated survey and monitoring of native island forest biota. Biodiv. Cons. 2018, 27, 2567-2586. [CrossRef]

37. Marschner, H. Marschner's Mineral Nutrition of Higher Plants, 3rd ed.; Academic Press: Waltham, MA, USA, 2011.

38. Neugebauer, K.; Broadley, M.R.; El-Serehy, H.A.; George, T.S.; McNicol, J.W.; Moraes, M.F.; White, P.J. Variation in the angiosperm ionome. Physiol. Plantarum 2018, 163, 306-322. [CrossRef] [PubMed]

39. Grove, T.S.; O'Connell, A.M.; Malajczuk, N. Effects of fire on the growth, nutrient content and rate of nitrogen fixation of the cycad Macrozamia riedlei. Aust. J. Bot. 1980, 28, 271-281. [CrossRef]

40. Watanabe, T.; Broadley, M.R.; Jansen, S.; White, P.J.; Takada, J.; Satake, K.; Takamatsu, T.; Tuah, S.J.; Osaki, M. Evolutionary control of leaf element composition in plants. New Phytol. 2007, 174, 516-523. [CrossRef] [PubMed]

41. Krieg, C.; Watkins, J.E.; Chambers, S.; Husby, C.E. Sex-specific differences in functional traits and resource acquisition in five cycad species. AoB PLANTS 2017, 9, plx013. [CrossRef] [PubMed]

42. Zhang, Y.-J.; Sack, L.; Cao, K.-F.; Wei, X.-W.; Li, N. Speed versus endurance tradeoff in plants: Leaves with higher photosynthetic rates show stronger seasonal declines. Sci. Rep. 2017, 7, 42085. [CrossRef] [PubMed]

43. Zhang, Y.; Cao, K.; Sack, L.; Li, N.; Wei, X.; Goldstein, G. Extending the generality of leaf economic design principles in the cycads, an ancient lineage. New Phytol. 2015, 206, 817-829. [CrossRef] [PubMed]

44. Álvarez-Yépiz, J.C.; Cueva, A.; Dovčiak, M.; Teece, M.; Yepez, E.A. Ontogenetic resource-use strategies in a rare long-lived cycad along environmental gradients. Conserv. Physiol. 2014, 2. [CrossRef] [PubMed]

45. Marler, T.E.; Ferreras, U.F. Disruption of Leaf Nutrient Remobilization in Coastal Cycas Trees by Tropical Cyclone Damage. J. Geogr. Nat. Disast. 2015, 5, 142. [CrossRef]

46. Marler, T.E.; Ferreras, U.F. Current status, threats and conservation needs of the endemic Cycas wadei Merrill. J. Biodivers. Endanger. Species 2017, 5, 193. [CrossRef]

47. Brummitt, N.A.; Bachman, S.P.; Griffiths-Lee, J.; Lutz, M.; Moat, J.F.; Farjon, A.; Donaldson, J.S.; Hilton-Taylor, C.; Meagher, T.R.; Albuquerque, S.; et al. Green plants in the red: A baseline global assessment for the IUCN sampled Red List Index for plants. PLoS ONE 2015, 10, e0135152. [CrossRef] [PubMed]

48. Fragniere, Y.; Bétrisey, S.; Cardinaux, L.; Stoffel, M.; Kozlowski, G. Fighting their last stand? A global analysis of the distribution and conservation status of gymnosperms. J. Biogeogr. 2015, 42, 809-820. [CrossRef]

49. Marler, P.N.; Marler, T.E. An assessment of Red List data for the Cycadales. Trop. Conserv. Sci. 2015, 8, 1114-1125. [CrossRef]

(C) 2018 by the authors. Licensee MDPI, Basel, Switzerland. This article is an open access article distributed under the terms and conditions of the Creative Commons Attribution (CC BY) license (http://creativecommons.org/licenses/by/4.0/). 